\title{
Fuzzy Logic Controller Effectiveness Evaluation through Comparative Memberships for Photovoltaic Maximum Power Point Tracking Function
}

\author{
Hussain Attia \\ Electrical, Electronics \& Communication Engineering Dept., School of Engineering American University of Ras Al \\ Khaimah, Uni Emirat Arab
}

\begin{tabular}{l} 
Article Info \\
\hline Article history: \\
Received Dec 13, 2017 \\
Revised Apr 12, 2018 \\
Accepted Aug 6, 2018 \\
\hline
\end{tabular}

\section{Keyword:}

Buck-boost DC-DC converter Fuzzy logic controller (FLC)

MATLAB

MPPT

Photovoltaic panel

Renewable energy

Variable membership

\begin{abstract}
Maximum Power Point Tracking (MPPT) is an important objective needed to gain maximum power from solar photovoltaic panel during the weather condition variation. Many studies and solutions are proposed in literature, most of them focus on the algorithm type which adopted for MPP tracking function i.e. DC-DC Boost converter. Among these algorithms, Fuzzy Logic Controller (FLC) demonstrates high quality performance by fast tracking response and robust effectiveness. This paper proposes a FLC by a new harmony of the input and the output variables through comparative study to the controller tracking behavior. To track the MPP, the proposed solution controls the change of duty cycle for PWM gate drive pulses width variation to drive the designed Buck-Boost DC-DC converter. MATLAB/Simulink software is selected to simulate the introduced controller. The simulation results are reflecting the promising indications to adopt the presented proposal as an effective MPPT system for practical applications.
\end{abstract}

Copyright $(0) 2018$ Institute of Advanced Engineering and Science. All rights reserved.

\section{Corresponding Author:}

Hussain Attia,

Electrical, Electronics \& Communication Engineering Dept.,

American University of Ras Al Khaimah,

Ras Al Khaimah, 10021, Uni Emirat Arab.

Email: hattia@aurak.ac.ae

\section{INTRODUCTION}

Renewable energy solution is representing one of the most important solutions towards mitigate the negative consequences of fossil fuel using. These fuel effects which reflected on the environmental condition through increasing air pollution, ambient temperature, and global warming. [1]-[2]. Due to the merits of solar renewable energy representing by availability and easy use as well as cheap all lead to have highly priority in applications and in research studies. Solar panel is an array or a matrix of solar cells which are connected in serial and/or parallel to provide the desired voltage and current levels. The function of solar photovoltaic panel through the included cells is converting the incident sunlight to an equivalent electrical power. Solar panel effectiveness of efficiency is evaluated through the value of output power $\left(P_{P V}\right)$. This power is positively proportional with the value of panel voltage $\left(V_{P V}\right)$ and the value of panel output current $\left(I_{P V}\right)$ i.e. it is equal to the multiplication result of these two values $\left(P_{P V}=V_{P V} * I_{P V}\right)$ [3]-[5].

Many techniques and methods are proposed in literature to increase the level of photovoltaic panel output power. Some of these studies are focused on proposing a certain electromechanically systems track and follow the sunlight direction during the day timing [6]-[7]. The other are focusing on the algorithm type and the design of related power electronic system topology leading to gain a maximum power point (MPP) by tracking it during weather condition variation considering the PV panel output characteristics as reviewed 
in [8] with respect to stand-alone solar systems.. Maximum Power Point Tracking (MPPT) can be achieved when track the nonlinear behavior of PV panel to a certain point, this MPPT is located at the top of the panel power curve, and based on this fact all of algorithms are common in the objective of reaching to this [9]-[12]. The technique of short circuit current is demonstrated in [9] in which the approximately linear related between maximum power point current with short circuit current is considered. The work in [10] shows and analyzes the algorithm of Incremental Conductance (IC) which characterized by highly performance quality during the quick weather variation. The main drawback of this method is the high power losses which consumed in the four sensors of the MPPT system. Other technique was proposed in [11] based on the algorithm of Perturb \& Observe (P\&O), this algorithm is proposed for dynamic tracking to MPP during weather variation conditions between sunny and cloudy day hours, the main drawbacks of this method are representing by oscillated response during no change weather conditions and slow tracking speed during quick weather variation. The simplest MPPT technique is Constant Voltage (CV) which shown in [12], the technique is adopted based on the assumption of that approximately $76 \%$ of the open circuit voltage value is equal normal solar panel voltage during different irradiance. Low accuracy is the main demerit of this technique.

Recently Fuzzy Logic Controller (FLC) is proposing for MPPT function in many studies due to its merits of robust performance, fast MPP tracking response and the high stability during the stable weather condition [13]-[17]. Enhancement on Hill-Climbing MPPT technique is done in [13] through including FLC positive effect. In [14]-[15] fast and accurate performances are investigated for MPPT objective using a new fuzzy logic controller. Other module of FLC in shown in [16]-[17], this FLC module is characterized by high tracking speed and high stability avoiding the oscillated response at the weather variation that what exactly happened with respect to the technique of perturb \& observe process. Due to the positive specifications of fuzzy controller which mentioned in literature, This paper proposes a detailed comparative study of FLC and full design of the desired Buck-Boost DC-DC converter to guarantee receiving the MPP output power from PV panel regardless the environmental conditions variation.

To explain this paper clearly, the remaining is as follows: Section II demonstrates the currentvoltage and the power-voltage characteristics of a certain PV panel which under study. A detailed design of DC-DC converter is shown in Section III. Full explanation of all FLC details including Fuzzyfication, Fuzzy Inference Rules, and Defuzzification are demonstrated in Section IV. MATLAB/Simulink simulation process and results with analysis are shown in section V. The findings of this paper are summarized in conclusion section $\mathrm{V}$

\section{SOLAR PHOTOVOLTAIC PANEL}

The solar PV panel which is adopted in this study has $16 \%$ efficiency and other parameters of open voltage, short current, MPP voltage, current and power all are shown in Table 1.

The basic unit in solar PV panel is represented by the solar cell. This cell produces the electrical power during the falling of sunlight on the surface of the panel. The quantity of incident light and the value of the ambient temperature have different effect on the output power quantity. The PV cell behaves nonlinearly with respect to the output voltage, current and power [4]-[12]. Figure 1 shows the equivalent electrical circuit of the PV cell whereas the nonlinear behavior is demonstrated in (1), (2), and (3) in which the cell nonlinear V-I is characterized [17]. Tables and Figures are presented center, as shown below and cited in the manuscript.

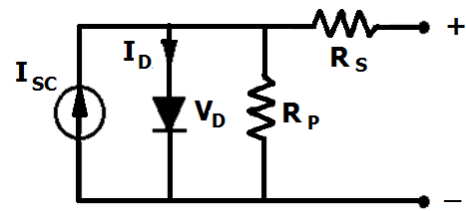

Figure 1. Equivalent electrical circuit of solar PV cell

$$
\begin{aligned}
& I_{D}=I_{0}\left(e^{\frac{V_{D}}{V_{T}}}-1\right) \\
& V_{P V}=V_{D}-R_{S} I_{P V} \\
& I_{S C}=I_{D}+\frac{V_{D}}{R_{P}}+I_{P V}
\end{aligned}
$$




$$
I_{P V}=I_{S C}-I_{D}-\frac{V_{D}}{R_{P}}
$$

where $I_{S C}$ is the total light generated current, $I_{D}$ is the diode current, $R_{P}$ is the shunt resistor, $I_{P V}$ is the panel output current, and $R_{S}$ is the serial resistor. Figure 2 and Figure 3 are shown the I-V and P-V characteristics of the selected PV Poly Crystalline module (PPS260P-60-STC) at different conditions of irradiance ambient temperature respectively. The two figure are showing that the output power is affected positively during the increasing of the incident solar light (irradiance), whereas the temperature increment effects negatively on the produced power of the solar panel

Table 1. PV Poly Crystalline model (PPS260P-60-STC Panel) specifications

\begin{tabular}{ccc}
\hline Peak Power & Pmax & $260 \mathrm{~W}$ \\
\hline Efficiency & $\eta$ & $16 \%$ \\
Rated Voltage & Vmpp & $31.1 \mathrm{~V}$ \\
Rated Current & Impp & $8.37 \mathrm{~A}$ \\
Open Circuit Voltage & Voc & $38.1 \mathrm{~V}$ \\
Short Circuit Current & Isc & $8.98 \mathrm{~A}$ \\
Power tolerance & $\mathrm{P}$ & $0-3 \%$ \\
Maximum System Voltage & UL & $1000 \mathrm{~V}$ \\
Temperature Coefficients & Power $(\mathrm{P})$ & $-0.41 \% /{ }^{\circ} \mathrm{C}$ \\
\hline
\end{tabular}

\section{PROPOSED METHODOLOGY}

\subsection{Buck-Boost DC-DC Converter Design}

The function of Buck-Boost DC-DC converter is controlling (stepping-up, or stepping-down) the output voltage by controlling the duty cycle of the PWM pulses. The output voltage $\left(\mathrm{V}_{\mathrm{o}}\right)$ has minus sign with linear relation with respect to the input voltage $\left(\mathrm{V}_{\text {in }}\right)$ as shown in (5). The value of $D$ is effects directly on the value of output voltage, when $\mathrm{D}$ of $(\mathrm{D}<0.5)$, the converter is able to buck (step down) the input voltage to have lower absolute output voltage whereas the converter is able to boost (step up) the input voltage for $(\mathrm{D}>0.5)[18]$.

$$
V_{o}=-V_{i n}\left(\frac{D}{1-D}\right)
$$

Using duty cycle controlling that to control the output voltage is done in many research studies [18]-[21]. To operate in Continuous Conduction Mode (CCM) which is simpler converter operating mode, the converter inductor minimum value can be determined from eq. (6) as explained in [22].

$$
L_{\min }=\frac{R(1-D)^{2}}{2 f}
$$

where $f$ represents the switching frequency, $R$ represents the load resistance. So to guarantee working within the CCM, the selected inductor value should be greater than the minimum inductor value of Eq. (6).

The minimum value of the converter capacitor $C$ can be calculated from output voltage ripple $\Delta V_{O}$ [22], as shown in Eq. (7), (8), and (9).

$$
\begin{aligned}
& \Delta V_{O}=\frac{V_{O} D T}{R C} \\
& \frac{\Delta V_{O}}{V_{O}}=\frac{D T}{R C} \\
& C=\frac{D}{R f} \frac{V_{O}}{\Delta V_{O}}
\end{aligned}
$$

where $V_{o}$ represents the converter output voltage, $D$ represents the duty cycle or conducting ratio of used power electronic switch which included in the converter.

The calculated minimum inductor and capacitor values at $30 \mathrm{kHz}$ switching frequency, voltage ripple $\left(\Delta V_{O} / V_{O}\right)=2 \%, D=0.5$, and load resistance of $\left(31.1 \mathrm{~V}^{\wedge} 2 / 260 \mathrm{~W}\right)=3.72 \Omega$ are $15.5 \mu \mathrm{H}$, and $224 \mu \mathrm{F}$ respectively. The selected inductor and capacitor values for the simulated Buck-Boost DC-DC converter are $0.5 \mathrm{mH}$, and $330 \mu \mathrm{F}$ respectively.

The diagram of the simulated Buck-Boost DC-DC converter based Fuzzy logic Controller (FLC) is shown in Figure 4. As shown in this figure, the system is started by the selected solar PV panel, which used 
to supply the DC link voltage to the converter. This converter is derived by pulse Width Modulation (PWM) pulses in which the duty cycle is controlled via the designed FLC for Maximum Power Point Tracking (MPPT) function.

\subsection{Sub section 2}

Due to the fast response and the high stability performance of fuzzy logic controller during the stable weather condition as demonstrated in introduction section. The process sequence of FLC is starting by receiving instantaneous values of solar panel output voltage and output current and then calculating the variable of error $\operatorname{Err}(n)$ and the variable of error change $\Delta \operatorname{Err}(n)$ using Eq. s (10) - (14). Based on the values and the trends of theses input variables to the FLC, the controller will produce the suitable change of duty cycle $\Delta D[23]-[24]$.

Duty cycle change $\Delta D$ will add to the constant duty cycle of 0.5 . The objective of this process of duty cycle controlling is to track the MPP point based on the fact of this point is located at the top position of power curve i.e. at $(\Delta P / \Delta V=0)$ as explained in Figure 5. To track this point, FLC is needed to control D value by doing a little or large step of increment or decrement of the duty cycle change $\Delta D$. Controlling the instantaneous value of $D$ will control the instantaneous value of converter output voltage during PWM technique. In other words, the width of PWM gate drive pulses will be controlled by controlling the value of $D$.

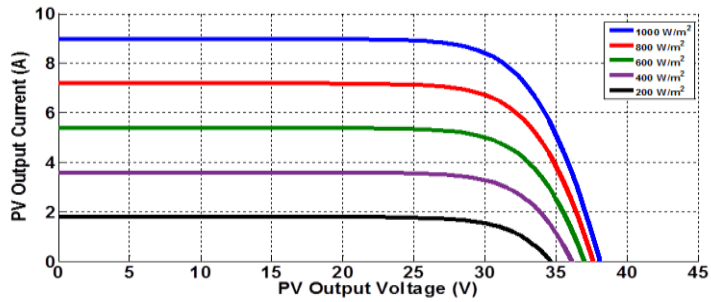

(a)

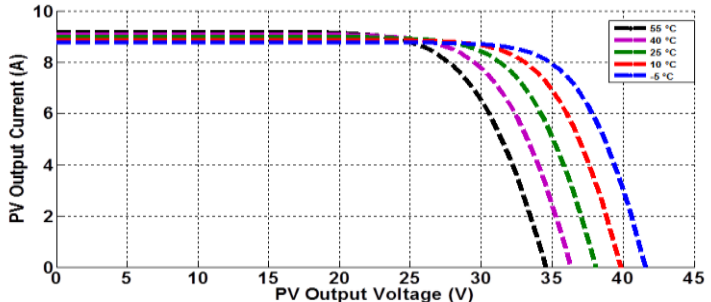

(b)

Figure 2. I-V characteristics of solar PV model (PPS260P-60-STC) at (a) Different irradiation levels at $25{ }^{\circ} \mathrm{C}$, (b) Different ambient temperature at $1000 \mathrm{~W} / \mathrm{m}^{2}$

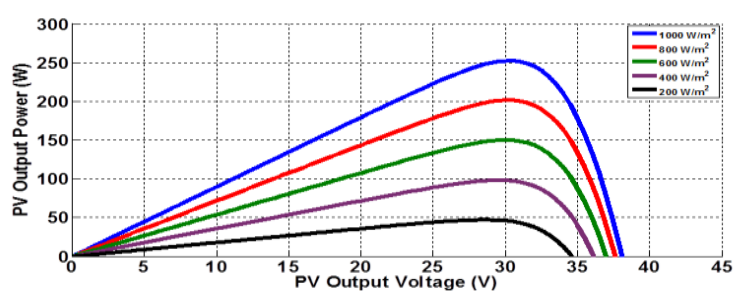

(a)

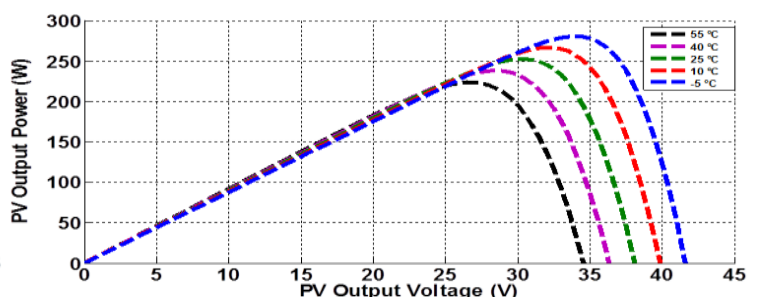

(b)

Figure 3. P-V characteristics of solar PV model (PPS260P-60-STC) at (a) different irradiation levels at $25^{\circ} \mathrm{C}$, (b) Different ambient temperature at $1000 \mathrm{~W} / \mathrm{m}^{2}$

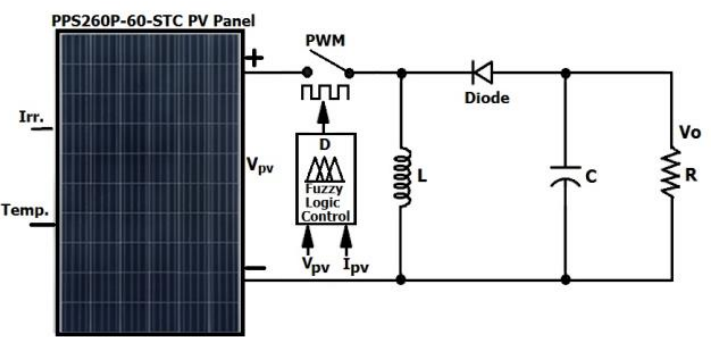

Figure 4. Buck-Boost DC-DC converter connection diagram 


$$
\begin{aligned}
& P(n)=V(n) * I(n) \\
& \Delta P(n)=P(n)-P(n-1) \\
& \Delta V(n)=V(n)-V(n-1) \\
& \operatorname{Err}(n)=\frac{\Delta P(n)}{\Delta V(n)} \\
& \Delta \operatorname{Err}(n)=\operatorname{Err}(n)-\operatorname{Err}(n-1)
\end{aligned}
$$

Generally, FLC controller consists of three blocks; Fuzzification block, Fuzzy Inference Rules block, and Defuzzification block. The effectiveness of the FLC depends on the internal design of these blocks. Figure 6 shows the stages of the proposed FLC including the process of solar panel voltage and current before controller and the adder stage of duty cycle after controller. The function of the Fuzzification block is receiving the input variables of the realistic domain and converting them to linguistic variables to be in suitable domain of the next fuzzy blocks. The desired five levels which are selected to represent the input linguistic variable of Error (n) or $\operatorname{err}(n)$ under the following names NL (Negative Large) level, NS (Negative Small) level, ZP (Zero Position), PS (Positive Small) level, and PL (Positive Large) level. On the other hand, the desired three levels which are selected to represent the input linguistic variable of $\Delta \operatorname{Err}$ or $\operatorname{Derr}(n)$ that named as follows; NS (Negative Small) level, ZP (Zero Position), and PS (Positive Small) level. The designed linguistic output variable names which are representing the values of the produced duty cycle change $\Delta D$ or $D D$ that are as follow; NB (Negative Big) value, NS (Negative Small) value, ZP (Zero Position) value, PS (Positive Small) value, and PB (Positive Big) value. The block of Fuzzy Inference Rules is designed based on Mamdani method; this block is including the desired inference rules. Defuzzification block represents the third block in FLC which is working on producing the realistic $\Delta D$ or $D D$ controlled value using center of gravity method. Based on $\Delta D$ or $D D$ value (negative or positive), the converter will work on bucking (step down) or boosting (step up) function respectively to track the maximum power point.

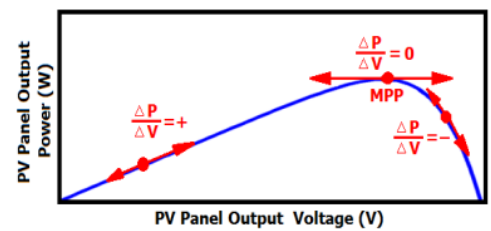

Figure 5. MPP position on solar PV panel power-voltage curve

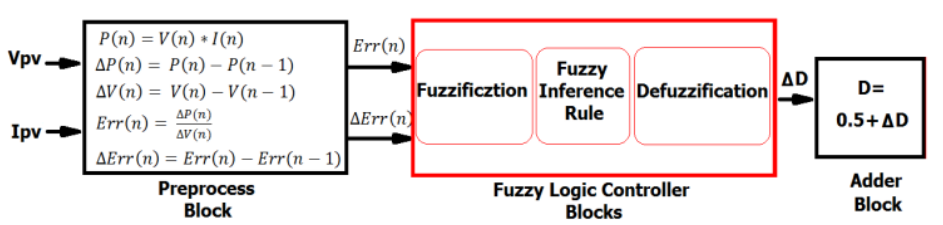

Figure 6. Detailed block diagram of the proposed MPP tacking system based on FLC

\section{COMPARITIVE SIMULATION RESULTS AND ANALYSIS}

This study focuses on showing the membership varying effect on the system performance with keeping fuzzy rules without changing. The input and output variables will be compared by other designed memberships at the rules conditions. Table II shows the fuzzy inference rules which are used without change for the two memberships. Figure 7 shows the first designed memberships arrangement of power error err or $\operatorname{Err}(n)$, power error change $\operatorname{Derr}$ or $\Delta \operatorname{Err}(n)$, duty cycle change $D D$ or $\Delta D(n)$, surface view of all memberships, and load power. The FLC is evaluated through monitoring the load power during four equal time intervals for a certain irradiance level $(1000,600,800,1000) \mathrm{W} / \mathrm{m} 2$. Figure 7 shows a regular memberships arrangement for the same variables and parameters sequence whereas Figure 8 shows the other designed memberships arrangement tat the same time and irradiance arrangement. The conclusion from Figure 7 and Figure 8 is that the levels of the output power from the solar PV panel are different between the two memberships groups in addition to the power level of Figure 8 is higher than of Figure 7. In other words, the FLC of the second memberships group of Figure 8 is more efficient in MPPT function than the first group of Figure 7. The membership arrangement difference is effect positively on the value of output power by unequal focusing the membership of the input and output variables. The focusing around zero error position leads to enhance the FLC effectiveness and this is done by accurate controlling to the duty cycle $D$. 

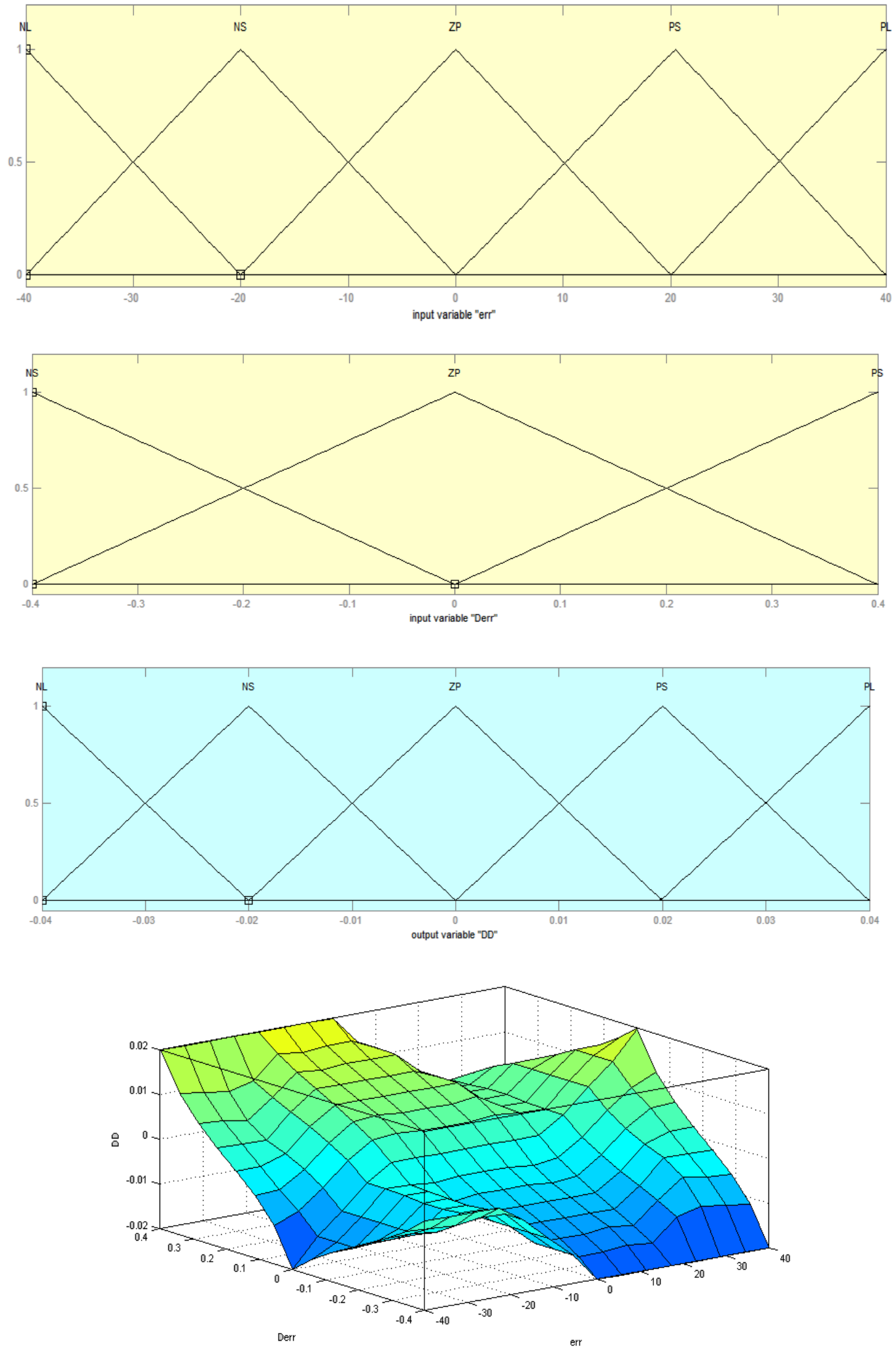


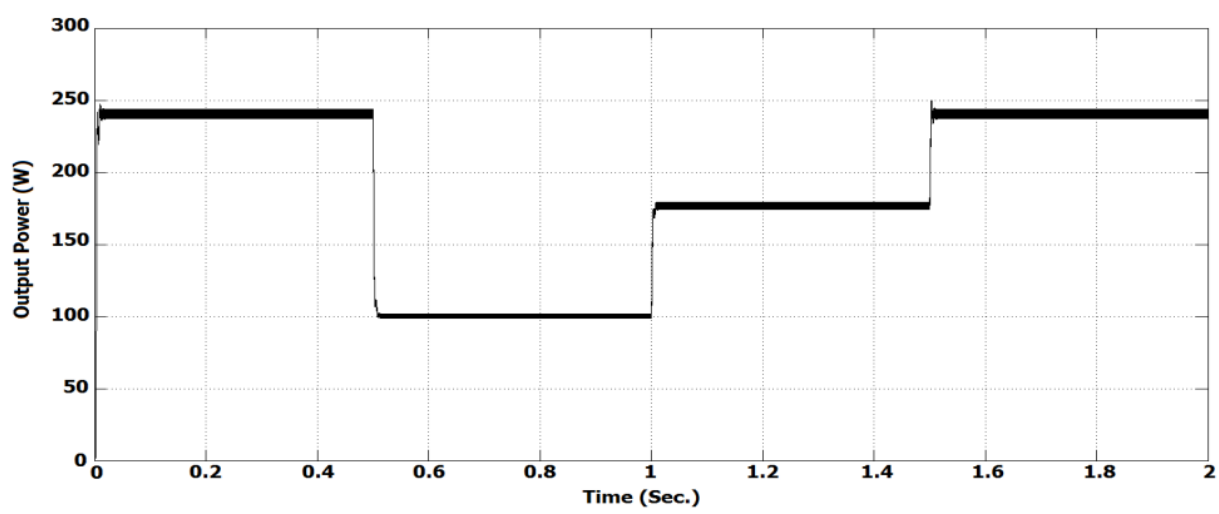

Figure 7. FLC steps for different irradiance of conventional arrangement from top to down; Membership function of power error err(n), membership function of power error change Derr(n), membership function of duty cycle change DD (n), surface view of all memberships, and Load delivered power
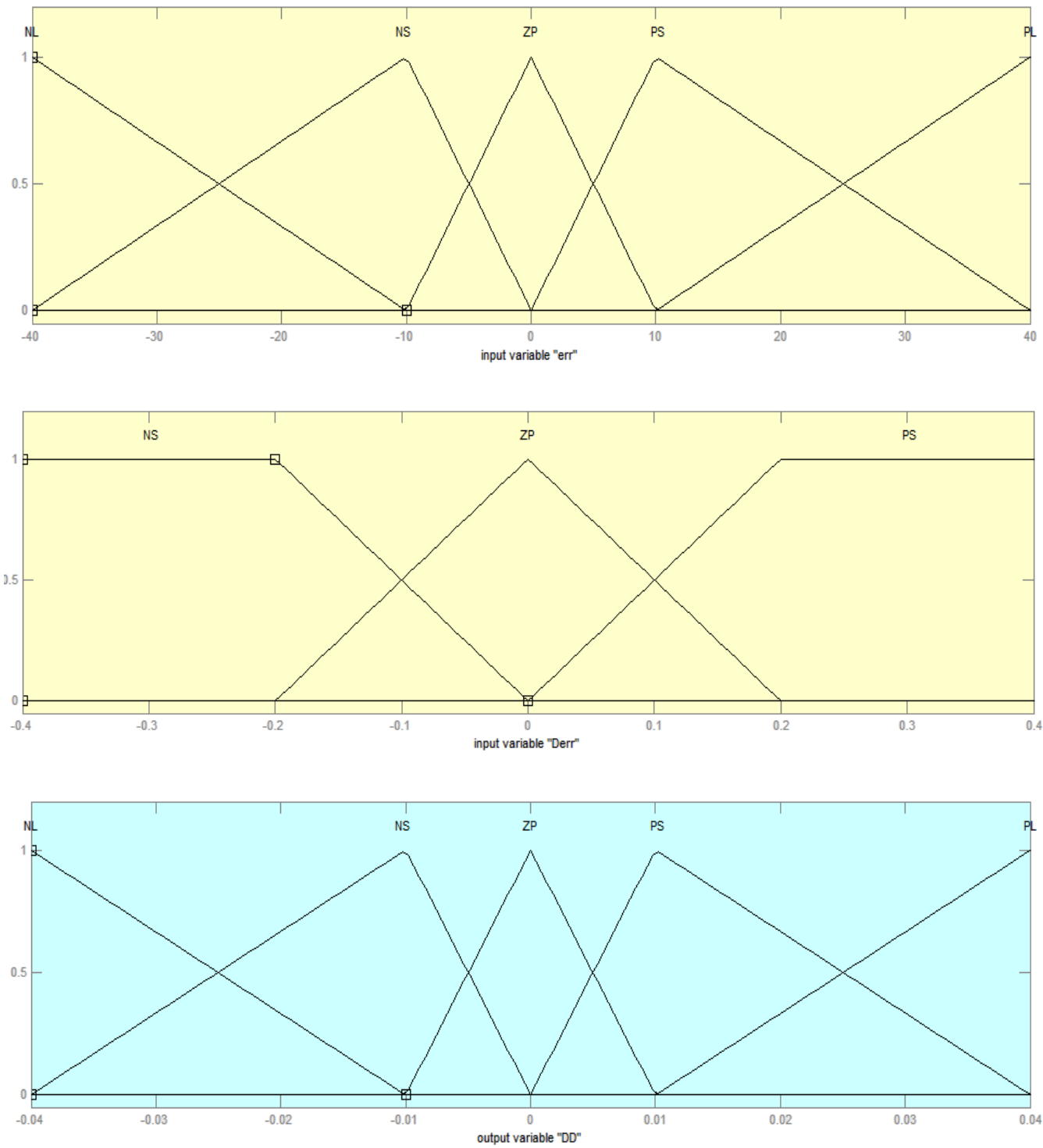

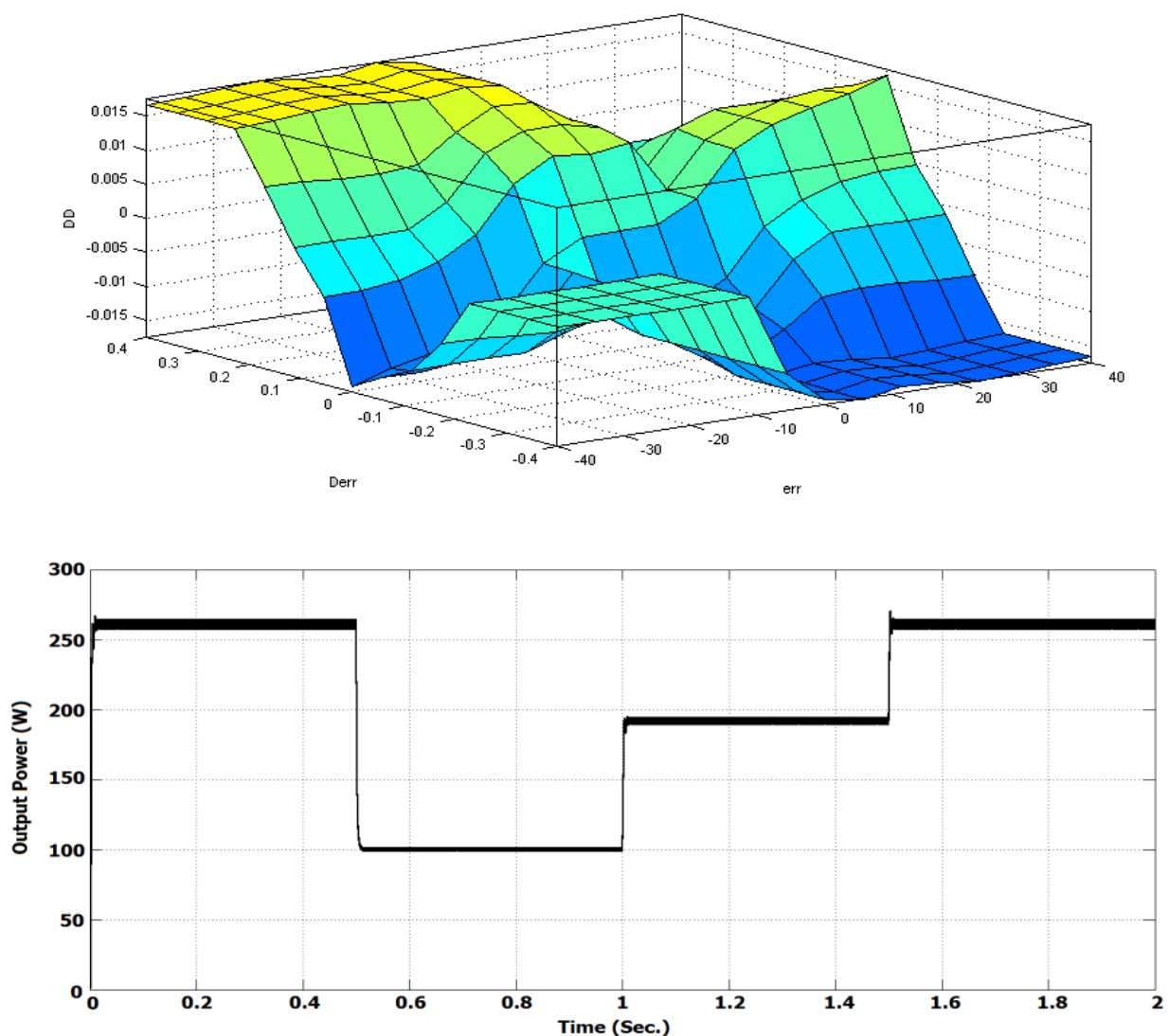

Figure 8. FLC steps for different irradiance of focused arrangement from top to down; Membership function of power error err(n), membership function of power error change Derr(n), membership function of duty cycle change DD (n), surface view of all memberships, and Load delivered power

\begin{tabular}{|c|c|c|}
\hline No & If & Then \\
\hline 1 & (err is NL) and (Derr is NS) & (DD is $\mathrm{ZP})$ \\
\hline 2 & (err is NL) and (Derr is ZP) & (DD is NS) \\
\hline 3 & (err is NL) and (Derr is PS) & (DD is PS) \\
\hline 4 & (err is NS) and (Derr is NS) & (DD is $\mathrm{ZP}$ ) \\
\hline 5 & (err is NS) and (Derr is ZP) & (DD is $\mathrm{ZP}$ ) \\
\hline 6 & (err is NS) and (Derr is PS) & (DD is PS) \\
\hline 7 & (err is $\mathrm{ZP}$ ) and (Derr is NS) & (DD is NS) \\
\hline 8 & (err is $\mathrm{ZP}$ ) and (Derr is $\mathrm{ZP}$ ) & (DD is $\mathrm{ZP}$ ) \\
\hline 9 & (err is ZP) and (Derr is PS) & (DD is PS) \\
\hline 10 & (err is PS) and (Derr is NS) & (DD is NS) \\
\hline 11 & (err is PS) and (Derr is ZP) & (DD is $\mathrm{ZP}$ ) \\
\hline 12 & (err is PS) and (Derr is PS) & (DD is $\mathrm{ZP}$ ) \\
\hline 13 & (err is PL) and (Derr is NS) & (DD is NS) \\
\hline 14 & (err is PL) and (Derr is ZP) & (DD is PS) \\
\hline 15 & (err is PL) and (Derr is PS) & (DD is $\mathrm{ZP})$ \\
\hline
\end{tabular}

\section{CONCLUSION}

This paper firstly focuses on increasing the level of solar photovoltaic output power through MPPT function by designing the parameters set in Fuzzy Logic Controller. Fuzzy Logic Controller was proved the high effectiveness in fast and solid response. Based on the mentioned merits of FLC, this paper introduces a comparative design and simulated investigation about the FLC effectiveness evaluation for MPPT function. FLC effectiveness is evaluated by considering the effect of memberships modification of the input and output variables with keeping other parameters fixed without change. FLC demonstrates a higher effectiveness when doing more focusing to the shape of memberships around Zero error position. MATLAB/Simulink simulation 
results are reflecting higher load power and indicating clearing the effect of unequal memberships with narrow shape around zero error position.

\section{ACKNOWLEDGEMENTS}

The authors appreciate the financial support provided by school of engineering, American University of Ras Al Khaimah - UAE, www.aurak.ac.ae/en/school-of-engineering/

\section{REFERENCES}

[1] H. A. Attia, T. K. S. Freddy, H. S. Che, W. P. Hew, A. El Khateb, "Confined Band Variable Switching Frequency Pulse Width Modulation (CB-VSF PWM) for Single-Phase Inverter with LCL Filter”, IEEE Trans. Power Electronics, IEEE 2016.

[2] M. A. Razzak, W. T. Bhuiyan, N. I. Natasha, A. K. M. M. Islam, M. K. M. Amin "Design of a Grid-connected Photovoltaic Inverter with Maximum Power Point Tracking using Perturb and Observe Technique", IJPEDS, Vol. 7, No. 4, December 2016, pp. 1212 1220

[3] YI Al-Mashhadany, HA Attia, "Novel Design and Implementation of Portable Charger through Low-Power PV Energy System”, Advanced Materials Research 925, 2014, pp.495-499.

[4] Y. I. Al-Mashhadany, Hussain A. Attia, "High Performance for Real Portable Charger through Low-Power PV System, International Journal of Sustainable and Green Energy, Vol. 4, No. 3-1, (2015), pp. 14-18.

[5] R. Aparnathi, V. V. Dwivedi, "Maximum Power Point Tracking in PV System with Industry Applications," International Journal of Power Electronics and Drive System (IJPEDS), Vol. 3, No. 4, December 2013, pp. 417 423

[6] Hussain A. Attia, Beza N. Getu, Yousif I. Al-Mashhadany "Design and Simulation of Dual Axis Solar Tracker for Optimum Solar Energy Absorption”, EEECEGC2013, December 11-13, 2013, Dubai, UAE.

[7] Attia H.A., Getu B.N., "Design \& Simulation of a Solar Tracking System for Optimum Energy Absorption," International Journal of Thermal \& Environmental Engineering, Volume 8, No. 1 (2014) 17-24.

[8] M. A. Abdourraziq and M. Maaroufi, "Experimental Verification of the Main MPPT Techniques for Photovoltaic System", International Journal of Power Electronics and Drive Systems (IJPEDS), Vol. 8, No. 1, March 2017, pp. $384-391$

[9] Hadeed Ahmed Sher, Ali F. Murtaza, Abdullah Noman, Khaled E. Addoweesh, and Marcello Chiaberge, "An intelligent control strategy of fractional short circuit current maximum power point tracking technique for photovoltaic applications", JRSE, 7, , 013114, 2015.

[10] Tilak Thakur, Kuldeep Singh bedi, "Data Based MPPT Technique for Photovoltaic System", India Conference (INDICON), IEEE Conference: 16-18 Dec. 2011, Hyderabad, India.

[11] S. Hassan, B. Abdelmajid, Z. Mourad, S. Aicha, B. Abdenaceur, "An Advanced MPPT Based on Artificial Bee Colony Algorithm for MPPT Photovoltaic System under Partial Shading Condition", International Journal of Power Electronics and Drive System (IJPEDS), Vol. 8, No. 2, June 2017, pp. 647 653

[12] Hussain A. Attia, Y. I. Al-Mashhadany, Beza N. Getu, "Design and Simulation of a High Performance Standalone Photovoltaic System," ICREGA'14 - Renewable Energy: Generation and Applications, Springer Proceedings in Energy 2014, pp 683-697.

[13] B. N. Alajmi, K. H. Ahmed, S. J. Finney, and B. W. Williams, "Fuzzy-Logic-Control Approach of a Modified HillClimbing Method for Maximum Power Point in Microgrid Standalone Photovoltaic System", IEEE Trans. Power Elect., vol. 26, no. 4, Apr. 2011, pp. 1022-1030.

[14] Ahmad El Khateb, Nasrudin Abd Rahim, Jeyraj Selvaraj, and M. Nasir Uddin, "Fuzzy Logic Controller Based SEPIC Converter for Maximum Power Point Tracking”, IEEE Trans. ind. Appl., vol. pp. no. 99, Feb. 2014.

[15] A. H. El Khateba, N. Abd Rahima, J. Selvaraja, "Fuzzy logic control approach of a maximum power point employing SEPIC converter for standalone photovoltaic system", 3rd Int. Conf. on Sustainable Future for Human Security SUSTAIN 2012, Procedia Environmental Sciences 17, 2013, pp. 529 - 536

[16] R. Samuel Rajesh Babu, "A Comparative Analysis of Integrated Boost Flyback Converterusing PID and Fuzzy Controller”, International Journal of Power Electronics and Drive System (IJPEDS), Vol. 5, No. 4, April 2015, pp. 486 501.

[17] Subiyanto, A Mohamed, M A Hannan, "Maximum Power Point Tracking in Grid Connected PV System Using A Novel Fuzzy Logic Controller”, Proceedings of SCOReD 2009, 16-18 Nov. 2009, UPM Serdang, Malaysia.

[18] HA Attia, HW Ping, Y Al-Mashhadany, "Design and analysis for high performance synchronized inverter with PWM power control”, Clean Energy and Technology (CEAT), 2013 IEEE Conference, 265-270.

[19] Hussain Attia, Amjad Omar, Maen Takruri, Halah Y. Ali, "Pulse Width Modulation Based Decentralized Street LED Light", International Journal of Power Electronics and Drive System (IJPEDS), Vol. 8, No. 3, September 2017, pp. $1238 \sim 1247$.

Fuzzy Logic Controller Effectiveness Evaluation through Comparative Memberships ... (Hussain Attia) 
[20] Attia Hussain, Sagafinia Ali, "Novel Discrete Components Based Speed Controller for Induction Motor", International Journal of Power Electronics and Drive Systems (IJPEDS), Vol. 7, Iss. 4, (2016).

[21] Hussain A Attia, Amjad Omar, Maen Takruri, "Design of decentralized street LED light dimming system", Electronic Devices, Systems and Applications (ICEDSA), 2016 5th International IEEE Conference, 2016.

[22] Daniel W. Hart, "Power Electronics", Published by McGraw-Hill, New York, NY 10020, ISBN 978-0-07-338067-4, 2011, www.mhhe.com

[23] M. Kumar, S. R. Kapoor, R. Nagar, A. Verma, "Comparison between IC and Fuzzy Logic MPPT Algorithm Based Solar PV System using Boost Converter”, IJAREEIE, Vol. 4, Iss. 6, 2015, pp. 4927-4939.

[24] R. Rahmani, M. Seyedmahmoudian, S. Mekhilef and R. Yusof, "Implementation of fuzzy logic Maximum Power Point Tracking Controller for Photovoltaic System”, AJAS, 10 (3), 2013, pp. 209-218.

\section{BIOGRAPHY OF AUTHOR}

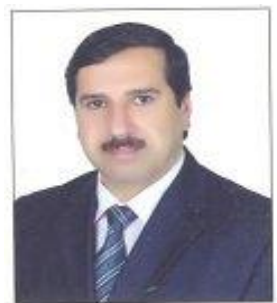

Hussain Attia earned his M.Sc. degree in electronic engineering from the University of Technology, Baghdad, in 1999. He earned his B.Sc. in electronic and communication engineering from the same university in 1991. M.Sc. Hussain's research interests: Power Electronics System, AC \& DC Speed Control Drives, Analog \& Digital Electronic Circuits Design, PWM Inverters (single phase $\&$ three phases). 